\title{
Correction to: Biodiversity and selection for scrapie resistance in sheep: genetic polymorphism in eight breeds of Algeria
}

\author{
AMAL DJAOUT ${ }^{1,2 *}$, BARBARA CHIAPPINI ${ }^{3}$, SEMIR-BECHIR-SUHEIL GAOUAR $^{4}$, \\ FARIDA AFRI-BOUZEBDA ${ }^{1}$, MICHELA CONTE $^{3}$, FAKHREDDINE CHEKKAL $^{5}$, \\ RACHID EL-BOUYAHIAOUI ${ }^{2}$, RACHID BOUKHARI $^{4}$, UMBERTO AGRIMI $^{3}$ and GABRIELE VACCARI ${ }^{3}$ \\ ${ }^{1}$ Laboratoire de Production Animale, Biotechnologie et Santé, Institut des Sciences Agrovétérinaires (ISAV), Université \\ Mohammed Cherif Messaadia, 41000 Souk-Ahras, Algeria \\ ${ }^{2}$ Institut National de la Recherche Agronomique d'Algérie (INRAA), 19000 Sétif, Algeria \\ ${ }^{3}$ Department of Food Safety, Nutrition and Veterinary Public Health, Istituto Superiore di Sanità, 00161 Rome, Italy \\ ${ }^{4}$ Laboratoire de Physiopathologie et Biochimie de la Nutrition (PpBioNut), Université Abou Bekr Belkaid, \\ 13000 Tlemcen, Algeria \\ ${ }^{5}$ Centre de Recherche Scientifique et Technique sur les Régions Arides (CRSTRA), 07000 Biskra, Algeria \\ *For correspondence. E-mail: djaout.ame108@gmail.com.
}

published online 19 September 2018

Correction to: Journal of Genetics, Vol. 97, No. 2, June 2018, pp. 453-461 (https://doi.org/10.1007/s12041-018-0932-x).

Figure 2 was printed incorrect in the article. The correct figure 2 is as follows.

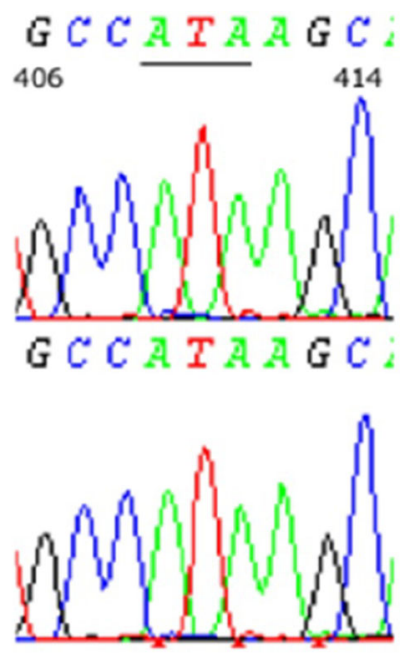

I137I

Figure 2. Electropherograms of the new $P R N P$ allele variants $\left(\mathrm{AI}_{137} \mathrm{RQ}\right.$ ) observed on Algerian sheep (nucleotides are numbered from the first ATG of the PRNP ORF). 